\title{
Retrospective Analysis of Vitamin D Levels in Patients with Chronic Renal Failure, Obesity, and Cancer
}

Kronik Böbrek Yetmezliği, Obezite ve Kanser Hastalarında Vitamin D Düzeylerinin Retrospektif İncelemesi Nilüfer Bulut ${ }^{1}$ (D) , Fatma Ölmez Budak ${ }^{1}$ (D) M. Çağatay Taşkapan ${ }^{1}$

1 Medical Biochemistry Department, Inönü University, Faculty of Medicine, Malatya/Turkey

\section{$\ddot{O Z E T}$}

AMAÇ: Çalışmamızda 2018-2021 yılları arasında Inönü Üniversitesi Turgut Özal Tıp Merkezine başvuran kronik böbrek yetmezliği, obezite ve kanser tanılı hastaların yaş, cinsiyet ve mevsimlere göre vitamin D düzeylerinin dağıımının incelenmesi amaçlandı.

GEREÇ VE YÖNTEM: Tanımlayıcı tipte olan çalışmamızda 01.01.2018-01.01.2021 tarihleri arasında Inönü Üniversitesi (iÜ) Turgut Özal Tıp Merkezine başvuran kronik böbrek yetmezliği, obezite ve kanser tanılı vitamin D seviyeleri ölçülen hastaların dosyaları taranarak retrospektif olarak değerlendirildi. Hastalar; yaş, cinsiyet ve örneklerin alındığı mevsimlere göre gruplandırıldı. 25(OH)D vitamini düzeyleri LC-MS/MS yöntemi ile analiz edilmişti. Hastalar vitamin D düzeyi bakımından eksik, yetersiz ve normal olarak sınıflandırıldı.

BULGULAR: Hastanemize başvuran 882 kronik böbrek yetmezliği hastasının \%63,3’ünde (n=558), 2894 obezite hastasının \%65,8'inde ( $n=1903)$ ve 1787 kanser hastasının \%54,9'unda $(n=981)$ vitamin D eksikliği tespit edildi. Hastalıklara göre vitamin $D$ düzeyleri arasında anlamlı bir fark vardı $(p<0.001)$.

SONUÇ: Hastanemize başvuran toplam 5563 kronik böbrek yetmezliği, obezite ve kanser hastasının; \%61,9'unda (n=3442) vitamin D eksikliği, \%23,1'inde ( $n=1284)$ vitamin D yetersizliği tespit edilirken, sadece \%15'inde ( $n=837)$ vitamin D seviyesi normal olarak bulundu. Vitamin D eksikliği bakımından \%57 oranla en fazla eksiklik obezite hastalarında görüldü. Çalısmamızda vitamin D düzeylerinin incelenen hastalıklara, mevsimlere ve yaş gruplarına bağlı olarak değiştiği görüldü.

Anahtar Kelimeler: vitamin D, kanser, kronik böbrek yetmezliği, obezite

\section{ABSTRACT}

OBJECTIVE: In our study, it was purposed to research the distribution of vitamin D according to age, sex, and seasons of the patients diagnosed with obesity, cancer, and chronic renal failure who applied to Inonu University Turgut Ozal Medical Center between 2018-2021.

MATERIALS AND METHODS: In our descriptive study, vitamin D measurements from 01.01.2018-01.01.2021 users who visited Inonu University Turgut Ozal Medical Center and were diagnosed with obesity, cancer, and chronic renal failure were scanned in their files and assessed retrospectively. The patients were grouped according to their sex, age, and seasons in which the samples were taken. 25(OH)D levels were analyzed by LC-MS/MS method. The patients were classified as deficient, inadequate, and normal in terms of vitamin D level

RESULTS: Vitamin D deficiency was monitored in 54.9\% ( $n=981)$ of 1787 cancer patients admitted to our hospital, $63.3 \%$ ( $n=558)$ of 882 chronic renal failure patients, and $65.8 \%(n=1903)$ of 2894 obese patients.

CONCLUSION: Of the 5563 obesity, cancer, and chronic renal failure patients who applied to our hospital; vitamin D deficiency was found in $61.9 \%(n=3442)$, vitamin D deficiency was found in $23.1 \%(n=1284)$, while vitamin $D$ level was found to be normal in only $15 \%$ ( $n=837)$. In terms of vitamin D deficiency, the highest deficiency was seen in obese patients with a rate of $57 \%$. In our study, it was observed that vitamin D levels vary depending on the diseases, seasons, and age groups examined.

Keywords: vitamin D, cancer, chronic kidney failure, obesity

\section{INTRODUCTION}

Vitamin D deficiency (VDD) is considered a global common epidemic not only in our country (Turkey) but also in the world (1). Although it has been known for many years that VDD plays a role in diseases for instances osteomalacia and rickets. Today, it is recorded that VDD has a part in the progress of diabetes mellitus, multiple sclerosis, chronic kidney disease, metabolic syndrome, epilepsy, and many diseases. It is thought that the benefits of its use as a supplement and vitamin D may play a part as an auxiliary factor in treatment $(2,3)$. Apart from these, it is also linked with a diagnosis of cancers, cardiovascular diseases, and

Yazışma Adresi/Address for Correspondence: Nilüfer Bulut, MD, İnönü University, Faculty of Medicine, Medical Biochemistry Department, Malatya/Turkey E-Posta/E-Mail: niluferdiller@hotmail.com || Tel: +90 5056276637

Received/Geliş Tarihi: 12.06.2021 || Accepted/Kabul Tarihi: 27.07.2021

Bu Eser Creative Commons Atıf-Gayriticari 4.0 Uluslararası Lisansı İle Lisanslanmıştır. This work is licensed under a Creative Commons

Attribution-NonCommercial 4.0 International License (CC BY-NC 4.0). 
Type 1 diabetes, and together with them simultaneously increased (3). These studies have also resulted in the study of the extraskeletal effects of vitamin D. It is stated that any improvement in the human body's vitamin D level will significantly influence the regulation of genes associated with cancer and cardiovascular diseases (4).

There are different assumptions regarding reference ranges of Vitamin D. The American Endocrine Society, one of the international health authorities, defines Vitamin D levels which below $20 \mathrm{ng} / \mathrm{mL}$ as a deficiency, which between 20-29 $\mathrm{ng} / \mathrm{mL}$ as insufficiency, and which $30 \mathrm{ng} / \mathrm{mL}$ and above as normal. (5). On the other hand, the World Health Organization defines vitamin D levels below $20 \mathrm{ng} / \mathrm{mL}$ as insufficiency and vitamin $D$ levels below $10 \mathrm{ng} / \mathrm{mL}$ as a deficiency. (6).

Chronic Renal Failure, (CRF), cancer, and obesity are also diseases in which VDD is common and thought to be linked with VDD. Our work aims to report the $25(\mathrm{OH}) \mathrm{D}$ deficiency by examining the vitamin D levels in CRF patients, obesity, and cancer who applied to our hospital from Malatya city and neighboring provinces and to determine its change in terms of age, sex, and season.

\section{MATERIAL \& METHODS}

This research was planned as a descriptive, cross-sectional analytical study. Before starting the study, ethical approval was obtained from Inonu University (IU) Health Sciences Non-Interventional Clinical Research Ethics Committee with decision number 2018/12-10, This study was carried out by retrospectively scanning the files of CRF, obesity, and cancer patients who applied to IU Turgut Ozal Medical Center between 01.01.2018 and 01.01.2021. In the study, all patients diagnosed by the relevant polyclinics were screened without any age restrictions. The intersection of the three groups in the study hadn't any patient. Patients with any two diseases were not included in the study. The youngest patient was 2 years old and the oldest patient was 96 years old in our study. In our study, 25(OH)D levels were measured by our biochemistry laboratory using the LC-MS/MS method. The measurement range for serum 25(OH)D was in the range of $20-70 \mathrm{ng} / \mathrm{mL}$. The ranges determined by the American Endocrine Society were taken as a reference for Vitamin D cut-off values. According to this, in our study, $25(\mathrm{OH})$ D levels for ranges $<20 \mathrm{ng} / \mathrm{mL}, 20-30 \mathrm{ng} / \mathrm{mL}$, and $>30$ $\mathrm{ng} / \mathrm{mL}$ were accepted as a deficiency, insufficiency, and normal, respectively.

\section{Statistical Analysis}

While evaluating the findings obtained in the study, SPSS (Statistical Package for Social Sciences) for Windows 20.00 program was used for statistical analysis. Descriptive statistics for continuous variables were summarized as mean and standard deviation (SD), and for categorical data in terms of frequency and percentage. For the comparison of categorical data, Pearson Chi-Square and Fisher-Exact tests were used. When there was a difference between groups, Bonferroni correction was applied for paired. Results were considered statistically significant for $p<0.01$.

\section{RESULTS}

The number of patients for vitamin D levels in terms of sex, diseases, and seasons of 5563 patients included in the study, min-max. values, arithmetic mean and SD measures are given in Table 1.

In the literature, VDD was described as serum 25(OH)D level $<20 \mathrm{ng} / \mathrm{mL}$ and insufficiency between 21 and $29 \mathrm{ng} / \mathrm{mL}$, and vitamin $D$ levels $>30 \mathrm{ng} / \mathrm{mL}$ were taken as the basis for optimal health (7). In our work, the classification of Vitamin $D$ levels was made by taking these values as a reference. Of the 5563 people in the study, 32\% ( $n=1783)$ were men and $68 \%(n=3780)$ were women. When the dispersion of vitamin $D$ levels in terms of sex for all patients was examined, there was not a significant difference between men and women as to vitamin D levels ( $p>0.05)$.

Considering that the three patients set were evaluated together, the highest VDD was $76.3 \%$ in winter $(n=1136)$, the highest insufficiency was 30.1\% $(n=459)$ in the summer season, and the highest normality was $19.7 \%$ in the summer season ( $n=301$ ). Of 1263 patients who applied to our hospital in the spring had a deficiency level of vitamin $D$ in $64.7 \%(n=817)$ and an insufficiency level of vitamin $D$ in $21.3 \%(n=269)$. Of 1526 patients who applied to our hospital in the summer had a deficiency level of Vitamin D in 50.2\% ( $n=766)$ and an insufficiency level of vitamin $D$ in $30.1 \%$ ( $n=$ 459). Of 1285 patients who applied to our hospital in autumn had a deficiency level of Vitamin D in 56.3\% ( $n=723)$ and an insufficient level of vitamin D in $24.8 \%(n=319)$. It was found deficiency level of Vitamin $D$ in $76.3 \%(n=1136)$ and an insufficient level of vitamin D in 15.9\% $(n=237)$ of 1489 patients who visited our hospital in winter. When these data were reviewed, there was a significant difference between vitamin $D$ levels due to seasons $\left(\chi^{\wedge} 2=248.681 ; p<0.01\right)$. 
Table 1. Vitamin D Levels by Sex, Diseases and Seasons

\begin{tabular}{|c|c|c|c|c|c|c|c|c|}
\hline & & & $n$ & $\%$ & Minimum & Maximum & Mean & SD \\
\hline \multirow{9}{*}{ Spring } & \multirow{3}{*}{ CRF } & Men & 92 & 52,5 & ,830 & 48,750 & 17,586 & 11,377 \\
\hline & & Women & 83 & 47,5 & 1,000 & 46,680 & 14,830 & 11,997 \\
\hline & & Total & 175 & 100 & ,830 & 48,750 & 16,279 & 11,723 \\
\hline & \multirow{3}{*}{ Obesity } & Men & 182 & 28,8 & 1,000 & 53,620 & 16,274 & 8,853 \\
\hline & & Women & 448 & 71,2 & ,720 & 63,020 & 16,565 & 10,435 \\
\hline & & Total & 630 & 100 & ,720 & 63,020 & 16,481 & 9,998 \\
\hline & \multirow{3}{*}{ Cancer } & Men & 132 & 28,8 & 1,000 & 52,420 & 16,782 & 11,278 \\
\hline & & Women & 326 & 71,2 & 1,000 & 66,200 & 21,385 & 14,284 \\
\hline & & Total & 458 & 100 & 1,000 & 66,200 & 20,058 & 13,635 \\
\hline \multirow{9}{*}{ Summer } & \multirow{3}{*}{ CRF } & Men & 125 & 48,1 & ,750 & 58,000 & 23,256 & 12,151 \\
\hline & & Women & 135 & 51,9 & 1,040 & 66,600 & 20,482 & 13,575 \\
\hline & & Total & 260 & 100 & ,750 & 66,600 & 21,816 & 12,960 \\
\hline & \multirow{3}{*}{ Obesity } & Men & 247 & 31,1 & 4,370 & 54,960 & 23,209 & 8,761 \\
\hline & & Women & 547 & 68,9 & ,980 & 60,920 & 18,855 & 10,446 \\
\hline & & Total & 794 & 100 & ,980 & 60,920 & 20,210 & 10,149 \\
\hline & \multirow{3}{*}{ Cancer } & Men & 118 & 25,0 & 2,230 & 69,230 & 22,073 & 11,864 \\
\hline & & Women & 354 & 75,0 & 1,000 & 68,100 & 22,765 & 13,227 \\
\hline & & Total & 472 & 100 & 1,000 & 69,230 & 22,592 & 12,891 \\
\hline \multirow{9}{*}{ Autumn } & \multirow{3}{*}{ CRF } & Men & 94 & 51,1 & 2,940 & 58,130 & 21,269 & 13,089 \\
\hline & & Women & 90 & 48,9 & 1,990 & 48,790 & 15,610 & 11,576 \\
\hline & & Total & 184 & 100 & 1,990 & 58,130 & 18,501 & 12,660 \\
\hline & \multirow{3}{*}{ Obesity } & Men & 209 & 31,3 & 4,340 & 55,890 & 22,083 & 10,486 \\
\hline & & Women & 459 & 68,7 & 1,000 & 61,200 & 17,862 & 9,843 \\
\hline & & Total & 668 & 100 & 1,000 & 61,200 & 19,183 & 10,230 \\
\hline & \multirow{3}{*}{ Cancer } & Men & 124 & 28,6 & 3,480 & 64,900 & 24,730 & 13,388 \\
\hline & & Women & 309 & 71,4 & 1,000 & 58,120 & 21,491 & 12,992 \\
\hline & & Total & 433 & 100 & 1,000 & 64,900 & 22,418 & 13,173 \\
\hline \multirow{9}{*}{ Winter } & \multirow{3}{*}{ CRF } & Men & 125 & 47,5 & 1,000 & 65,050 & 16,295 & 11,607 \\
\hline & & Women & 138 & 525 & ,950 & 67,110 & 14,789 & 11,892 \\
\hline & & Total & 263 & 100 & ,950 & 67,110 & 15,505 & 11,759 \\
\hline & \multirow{3}{*}{ Obesity } & Men & 215 & 26,8 & 1,090 & 69,090 & 12,880 & 8,001 \\
\hline & & Women & 587 & 73,2 & 1,000 & 69,930 & 12,699 & 8,520 \\
\hline & & Total & 802 & 100 & 1,000 & 69,930 & 12,747 & 8,379 \\
\hline & \multirow{3}{*}{ Cancer } & Men & 120 & 28,3 & 1,000 & 54,580 & 13,010 & 9,283 \\
\hline & & Women & 304 & 71,7 & ,930 & 68,480 & 18,001 & 12,537 \\
\hline & & Total & 424 & 100 & ,930 & 68,480 & 16,589 & 11,912 \\
\hline
\end{tabular}

SD: standard deviation, $n$ : number

When the ages included in the study were examined, the lowest age in the CRF group was 2, the highest age was 92; in the obesity group, the lowest age was 3 , the highest age was 81; in the cancer group, the lowest age was 3 and the highest age was 96. In terms of age groups, the highest VDD among the total patients was in the ages group of 18-34 which constitute $14 \%$ of all patients $(n=775)$ and the highest deficiency was $4.4 \%$ in the $0-17$ age group $(n=245)$ and the highest normality was detected in the $55+$ age group with a frequency of $5.8 \%(n=326)$. In the $0-17$ age group, $54.9 \%$ ( $n$ $=467$ ) of 850 patients received to our hospital had deficiency of vitamin $D$ levels and $28.8 \%(n=245)$ of them had insufficiency levels of vitamin D. In the 18-34 age group, $73.4 \%(n=775)$ of 1056 patients admitted to our hospital had deficiency levels and 17.3\% ( $\mathrm{n}=183)$ of them had insufficiency levels of vitamin D. In the 35-54 age group, 61\% ( $n=1151$ ) of 1886 patients received to our hospital had deficiency levels and $22.4 \%(n=460)$ of them had insufficiency levels of vitamin D. In the 55+ age group, 59.2\% ( $n=1049$ ) of 1771 patients admitted to our hospital had deficient levels and $22.4 \%(n=396)$ of them had insufficient levels of vitamin $\mathrm{D}$. There was a significant difference between vitamin $D$ levels according to age groups ( $p<0.01)$.

VDD was found in $63.3 \%(n=558)$ of 882 CRF patients, $65.8 \%$ ( $n=1903$ ) of 2894 obese patients and $54.9 \%(n=981)$ of 1787 cancer patients. While VDD levels were higher than both insufficiency and normal levels in terms of diseases $(p<0.01)$, 
no significant difference was found between insufficiency and normal levels.

Vitamin D levels of CRF patients were founded according to sex, seasons, and age groups, and a significant difference was found among vitamin $D$ levels in respect of all three factors (Table 2).

Vitamin D levels of obese patients were founded in terms of sex, seasons, and age groups, and a significant difference was found between vitamin $D$ levels as regards all three factors (Table 3).

Vitamin D levels of cancer patients were also analyzed in terms of sex, seasons, and age groups; while we found a significant difference between vitamin $D$ levels in terms of sex and seasons, no significant difference as regards age groups (Table 4).

Table 2. Vitamin D Levels in Chronic Renal Failure Patients by Sex, Seasons, and Age Groups

\begin{tabular}{|c|c|c|c|c|c|c|c|c|c|c|c|}
\hline \multicolumn{12}{|c|}{ Vitamin D Levels } \\
\hline & & \multicolumn{2}{|c|}{ Deficiency } & \multicolumn{2}{|c|}{ Insufficient } & \multicolumn{2}{|c|}{ Normal } & \multicolumn{4}{|c|}{ Total } \\
\hline & & $\mathrm{n}$ & $\%$ & $\mathrm{n}$ & $\%$ & $\mathbf{n}$ & $\%$ & $\mathrm{n}$ & $\%$ & $\chi^{2}$ & $p$ \\
\hline \multirow{3}{*}{ Sex } & Men & 253 & 58,0 & 89 & 20,4 & 94 & 21,6 & 436 & 100 & & \\
\hline & Women & 305 & 68,4 & 73 & 16,4 & 68 & 15,2 & 446 & 100 & 10,487 & 0,005 \\
\hline & Total & 558 & 63,3 & 162 & 18,4 & 162 & 18,4 & 882 & 100 & & \\
\hline \multirow{5}{*}{ Seasons } & Spring & 119 & 68,0 & 30 & 17,1 & 26 & 14,9 & 175 & 100 & & \\
\hline & Summer & 128 & 49,2 & 66 & 25,4 & 66 & 25,4 & 260 & 100 & & \\
\hline & Autumn & 118 & 64,1 & 28 & 15,2 & 38 & 20,7 & 184 & 100 & 37,471 & 0,000 \\
\hline & Winter & 193 & 73,4 & 38 & 14,4 & 32 & 12,2 & 263 & 100 & & \\
\hline & Total & 558 & 63,3 & 162 & 18,4 & 162 & 18,4 & 882 & 100 & & \\
\hline \multirow{5}{*}{$\begin{array}{l}\text { Age } \\
\text { Groups }\end{array}$} & $0-17$ & 31 & 44,3 & 15 & 21,4 & 24 & 34,3 & 70 & 100 & & \\
\hline & $18-34$ & 64 & 75,3 & 9 & 10,6 & 12 & 14,1 & 85 & 100 & & \\
\hline & $35-54$ & 134 & 64,1 & 47 & 22,5 & 28 & 13,4 & 209 & 100 & 24,618 & 0,000 \\
\hline & $55+$ & 329 & 63,5 & 91 & 17,6 & 98 & 18,9 & 518 & 100 & & \\
\hline & Total & 558 & 63,3 & 162 & 18,4 & 162 & 18,4 & 882 & 100 & & \\
\hline
\end{tabular}

$\chi^{\wedge} 2$ : chi-square, $p$ : probability, n: number \%: percentage

Table 3. Vitamin D Levels in Obesity Patients by Sex, Seasons and Age Groups

\begin{tabular}{|c|c|c|c|c|c|c|c|c|c|c|c|}
\hline \multicolumn{12}{|c|}{ Vitamin D Levels } \\
\hline & & \multicolumn{2}{|c|}{ Deficiency } & \multicolumn{2}{|c|}{ Insufficient } & \multicolumn{2}{|c|}{ Normal } & \multicolumn{2}{|c|}{ Total } & \multirow[b]{2}{*}{$\chi^{2}$} & \multirow[b]{2}{*}{ p } \\
\hline \multirow{4}{*}{ Sex } & & n & $\%$ & $\mathrm{n}$ & $\%$ & $\mathrm{n}$ & $\%$ & n & $\%$ & & \\
\hline & Men & 510 & 59,8 & 235 & 27,5 & 108 & 12,7 & 853 & 100 & & \\
\hline & Women & 1393 & 68,3 & 466 & 22,8 & 182 & 8,9 & 2041 & 100 & 20,494 & 0,000 \\
\hline & Total & 1903 & 65,8 & 701 & 24,2 & 290 & 10 & 2894 & 100 & & \\
\hline \multirow{5}{*}{ Seasons } & Spring & 435 & 69,0 & 143 & 22,7 & 52 & 8,3 & 630 & 100 & & \\
\hline & Summer & 419 & 52,8 & 252 & 31,7 & 123 & 15,5 & 794 & 100 & & \\
\hline & Autumn & 390 & 58,4 & 190 & 28,4 & 88 & 13,2 & 668 & 100 & 183,079 & 0,000 \\
\hline & Winter & 659 & 82,2 & 116 & 14,5 & 27 & 3,4 & 802 & 100 & & \\
\hline & Total & 1903 & 65,8 & 701 & 24,2 & 290 & 10 & 2894 & 100 & & \\
\hline \multirow{5}{*}{$\begin{array}{l}\text { Age } \\
\text { Groups }\end{array}$} & $0-17$ & 362 & 55,7 & 200 & 30,8 & 88 & 13,5 & 650 & 100 & & \\
\hline & $18-34$ & 624 & 75,4 & 147 & 17,8 & 57 & 6,9 & 828 & 100 & & \\
\hline & $35-54$ & 703 & 65,9 & 255 & 23,9 & 109 & 10,2 & 1067 & 100 & 67,232 & 0,000 \\
\hline & $55+$ & 214 & 61,3 & 99 & 28,4 & 36 & 10,3 & 349 & 100 & & \\
\hline & Total & 1903 & 65,8 & 701 & 24,2 & 290 & 10 & 2894 & 100 & & \\
\hline
\end{tabular}

$\chi^{\wedge} 2$ : chi-square, $p$ : probability, $n$ : number \%: percentage

\section{DISCUSSION}

The prevalence of VDD in the community is $20-50 \%$, and deficiency levels have been reported up to $70-80 \%$ in CRF patients (8). A group of researchers aiming to assess the vitamin D status of hemodialysis patients in Germany found that approximately one-third (32.7\%) of the patients had severe VDD and $47 \%$ had insufficiency. They stated that the incidence of cancer is also high among the same individuals, emphasizing the cancer-affecting properties of vitamin $D$ for the risk of cancer disease seen in kidney patients, and stated that more studies are needed (9). Epidemiological studies have indicated that low 25(OH)D levels are free predictors of disease progression and mortality in patients with CKD (Chronic Kidney Disease) and End-Stage Renal Disease (ESRD) (10). Grahame found that 39\% of 257 CRF patients 
had low serum 25(OH)D levels and lower levels were linked with women's sex ( $p=0.000$ for each). In the study, 25(OH)D levels also differed in terms of the season ( $p=0.018)$, peaking in autumn and reaching the lowest level in spring (11). Li et al. demonstrated the relationship between vitamin $\mathrm{D}$ and the renin-angiotensin system using animal models. Accordingly, it has been hypothesized that vitamin $D$ plays a key role in the renocardiovascular system and acts as a negative endocrine regulator in the renin-angiotensin system. In this respect, it has been illuminating the molecular effects of vitamin $D$ analogs, the renin-angiotensin system, and the therapeutic renin inhibitors that control blood pressure (12).

Table 4. Vitamin D Levels in Cancer Patients by Sex, Seasons and Age Groups

\begin{tabular}{|c|c|c|c|c|c|c|c|c|c|c|c|}
\hline \multicolumn{12}{|c|}{ Vitamin D Levels } \\
\hline & & \multicolumn{2}{|c|}{ Deficiency } & \multicolumn{2}{|c|}{ Insufficient } & \multicolumn{2}{|c|}{ Normal } & \multicolumn{2}{|c|}{ Total } & \multirow[b]{2}{*}{$\chi^{2}$} & \multirow[b]{2}{*}{ p } \\
\hline \multirow{4}{*}{ Sex } & & $\mathrm{n}$ & $\%$ & $\mathrm{n}$ & $\%$ & $\mathrm{n}$ & $\%$ & $\mathrm{n}$ & $\%$ & & \\
\hline & Men & 306 & 61,9 & 94 & 19,0 & 94 & 19,0 & 494 & 100 & & \\
\hline & Women & 675 & 52,2 & 327 & 25,3 & 291 & 22,5 & 1293 & 100 & 14,131 & 0,001 \\
\hline & Total & 981 & 54,9 & 421 & 23,6 & 385 & 21,5 & 1787 & 100 & & \\
\hline \multirow{5}{*}{ Seasons } & Spring & 263 & 57,4 & 96 & 21,0 & 99 & 21,6 & 458 & 100 & & \\
\hline & Summer & 219 & 46,4 & 141 & 29,9 & 112 & 23,7 & 472 & 100 & & \\
\hline & Autumn & 215 & 49,7 & 101 & 23,3 & 117 & 27,0 & 433 & 100 & 52,344 & 0,000 \\
\hline & Winter & 284 & 67,0 & 83 & 19,6 & 57 & 13,4 & 424 & 100 & & \\
\hline & Total & 981 & 54,9 & 421 & 23,6 & 385 & 21,5 & 1787 & 100 & & \\
\hline \multirow{5}{*}{$\begin{array}{l}\text { Age } \\
\text { Groups }\end{array}$} & $0-17$ & 74 & 56,9 & 30 & 23,1 & 26 & 20,0 & 130 & 100 & & \\
\hline & $18-34$ & 87 & 60,8 & 27 & 18,9 & 29 & 20,3 & 143 & 100 & & \\
\hline & $35-54$ & 314 & 51,5 & 158 & 25,9 & 138 & 22,6 & 610 & 100 & 6,118 & 0,410 \\
\hline & $55+$ & 506 & 56,0 & 206 & 22,8 & 192 & 21,2 & 904 & 100 & & \\
\hline & Total & 981 & 54,9 & 421 & 23,6 & 385 & 21,5 & 1787 & 100 & & \\
\hline
\end{tabular}

$\chi^{\wedge}$ 2: chi-square, $p$ : probability, $n$ : number \%: percentage

In our study, we found that $63.3 \%$ of the patients followed up with the diagnosis of CRF had deficient, $18.4 \%$ insufficient, and $18.4 \%$ normal serum $25(\mathrm{OH}) \mathrm{D}$ levels. In addition, the vitamin $D$ levels of the patients were examined in terms of sex, seasons, and age groups, and a significant difference was "found among vitamin D levels" in terms of all three factors. For $25(\mathrm{OH}) \mathrm{D}$ deficiency in this patient group; the highest rate in terms of sex was found in men (68.4\%), the highest rate in terms of seasons was found in winter (73.4\%), and the highest rate in terms of age was found in the age group of 18-34 (75.3\%). Although there are studies on VDD in CRF patients, there is no study focusing on VDD in these patients in terms of age, sex, and seasonality. There is an impaired vitamin D metabolism in patients with CRF. Although there are many unanswered questions on this issue, what is apparent is that VDD is severe in kidney patients and that the use of supplements can be beneficial in these patients.

Obesity occurs when many factors come together. Although diet, genes, or other lifestyles are thought to have a major effect on the development of obesity, the role of vitamins cannot be neglected in this process. It is a controversial issue whether VDD is a result/cause of obesity (13). In the study conducted by Vimaleswaran et al., it was suggested that while high BMI causes low 25(OH)D level, while low 25(OH)D has little effect on obesity (14). McGill et al. were realized that obese patients have rarely vitamin D sufficiency, and there is an adverse "relationship between serum" 25(OH)D levels and body weight, BMI (body mass index), waist circumference, and total body fat mass (15). The relationship "between vitamin D and" obesity can be declared by the effect of vitamin $\mathrm{D}$ on adipogenesis regulating factors in adipose tissue and on inflammation and energy homeostasis in adipocytes (16). In a meta-analysis study on VDD in obese patients, the prevalence of VDD was 35\% higher in obese than in the control group. (17). It has been stated that increased PTH level secondary to hypovitaminosis D stimulates lipid anabolism by increasing $\mathrm{Ca} 2+$ directed to adipose tissue $(18,19)$, and treatment with VD in 3T3-L1 preadipocytes has been shown to inhibit adipogenesis through down-regulation of transcription factor C/EBPbeta. In addition, it was emphasized that 1,25(OH)D activates the WNT/beta-catenin pathway, resulting in the blockade of adipogenesis (19-21). In the work by Lagunova et al., the seasonal change and prevalence of VDD were assessed in different BMI, sex, and age categories in a population of 2126 
patients in Norway. For sex and age groups ( $<50$ years and $\geq 50$ years), an adverse relationship was found between BMI and serum $25(\mathrm{OH}) \mathrm{D}$ levels. The results show that one-third of women with a $\mathrm{BMI} \geq 40$ and one-two of men are vitamin $\mathrm{D}$ deficient (22).

Most of the studies reporting VDD in obese individuals have not been methodically evaluated for seasonal variations. However, Ernst et al. reported that there are significant seasonal changes in serum $25(\mathrm{OH}) \mathrm{D}$ levels and the prevalence of VDD in obese patients (23). A meta-analysis study also reported that VDD is linked with age, latitude, and obesity (17). Bischof et al. observed a seasonal change in 25(OH)D serum levels of 483 adults in 2002-2004. In this study, it was stated that 25(OH)D levels were minimum in January and increased until July. While evaluating the vitamin D status of the obese, it was recommended to consider BMI, age and seasons, and to consider more aggressive vitamin $D$ supplements for obese individuals (24). Lagunova et al. found that patients with a $\mathrm{BMl} \geq 30$ had serum $25(\mathrm{OH}) \mathrm{D}$ concentration approximately $20 \%$ lower than those of normal weight through the year, not just in summer. In addition, seasonal changes of 25(OH)D were not affected by $\mathrm{BMI}$ in women, while obese men had much smaller seasonal change and higher VDD than non-obese men. Obese men and women in the young age group have been reported to have low vitamin $D$ status not only in winter but also in summer. It has also been emphasized that about $40 \%$ of obese women and $75 \%$ of men have VDD in winter and spring, and about 25\% still have deficient levels in the summer. As the age group, the elder people (over 50 years old) with low BMI have found higher 25(OH)D values through the year, although the seasonal variation is not very large (22). In our study, it was found that serum 25(OH)D levels were insufficient and deficient in $90 \%$ of patients who were followed up with a diagnosis of obesity. In addition, vitamin $D$ levels were analyzed in terms of sex, seasons, and age groups, and a significant difference was found between vitamin $D$ levels in terms of all three factors. For $25(\mathrm{OH}) \mathrm{D}$ deficiency in this patient group; the highest rate in terms of sex was found in women (68.3\%), the highest rate in terms of seasons was found in winter (82.2\%), and the highest rate in terms of age was found in the age group of 18-34 (75.4\%). Although vitamin D supplementation has not been clearly shown to benefit the negative metabolic profile in obese patients, based on the results of our study, only $10 \%$ of 2894 obese patients had normal vitamin D levels; for this reason, it strengthens the possibility that VDD is a major agent that has not been revealed in the occurrence of the metabolic pattern in these patients.

In addition to being associated with important public health problems such as vitamin D, obesity, diabetes, and hypertension, there are many studies recently showing the link between VDD and cancer types (25). In the study of Öngen et al., it was stated that as one goes to the north pole, sun exposure decreases, and cancer and cancer-related mortality rates increase. This case strengthens the hypothesis that there may be a relationship between cancer and vitamin D levels. (26). Li et al stated that in recent studies and epidemiological studies, the protective role of vitamin $D$ against the risk of developing many kinds of cancer has been investigated. In these studies, it was emphasized that VDD causes an up in the risk of breast, lung, pancreatic, colorectal, ovarian bladder, thyroid, and kidney cancers. (27). Vitamin levels below $20 \mathrm{ng} / \mathrm{mL}$, which is the cut-off value for deficiency, have been linked with a rised risk of $30-50 \%$, especially for colon, prostate and breast cancer development, and an increased mortality rate from these cancers (26). In addition to the anti-cancer effects of vitamin $\mathrm{D}$ and its analogs, some studies have also been carried on the impacts of suppressing the proliferation of human cancer cells mediated by vitamin D receptors. (28). It has been looked into that Vitamin $D$ has a control function on genes that control cell proliferation, differentiation, apoptosis, and angiogenesis. In this respect, the result of vitamin $\mathrm{D}$ on cancer can be explained by the mechanism of inhibition of signals that trigger cell growth, cell proliferation, metastasis, and angiogenesis (29). In a recent study, it was shown that patients with serum 25(OH)D levels lower than $20 \mathrm{ng} / \mathrm{mL}$ have a high probability of having breast cancer (30). When vitamin $D$ and cancer disease are evaluated, there are studies in which values of $25(\mathrm{OH}) \mathrm{D}$ are lower in individuals with cancer than in healthy individuals. In the study that Shi et al. investigated vitamin D levels in individuals with cancer, it was stated that serum 25(OH)D levels were insufficient and deficient in $71 \%$ of 1940 people diagnosed with cancer. (31). In our study, in parallel with the findings of Shi et al., it was determined that $78.5 \%$ of the patients who were followed up with a diagnosis of cancer disease had insufficient and deficient serum 25(OH)D levels. In observational studies demonstrating the relationship between breast cancer and vitamin $D$, it has also been shown that the risk of breast cancer significantly decreases with 
high 25(OH)D levels (32). In a comprehensive meta-analysis study by Zhang et al. with 74655 participants, vitamin D supplementation found a significant $16 \%$ reduction in cancer-related mortality. More notably, the study reported that the reduction in cancer mortality was not seen with supplementation of the vitamin D2 form, but only with supplementation of the vitamin D3 form (33). In epithelial cells, the vitamin D receptor (VDR) and its ligand 1,25D contribute to the maintenance of the differentiated phenotype and support pathways that protect cells against endogenous and exogenous stresses. This provides a reduced risk for carcinogenic transformation (34). Tangpricha et al. injected colon cancer cells to mice whose predetermined plasma vitamin D levels. It was observed mice with vitamin D sufficiency had $40 \%$ smaller tumors (35). Leyssens et al. observed that $1,25(\mathrm{OH}) 2 \mathrm{D} 3$, the active form of vitamin D, reduced cell proliferation at certain concentrations in Caco-2, SW1417, and SW480-ADH colon cancer cell lines (36).

In one of the epidemiological studies focusing on latitudinal relationships while reported the link between sunlight and cancer, John et al. noticed significant decreases in prostate cancer risk in the south of the United States, where sun exposure is higher (37). Hanchette and Schwartz founded that there was an adverse correlation between the geographical spread of solar UV intensity and prostate cancer mortality in North America, and also there was a lower cancer mortality rate in the South compared to the North. (38). Freedman et al. explored that exposure to sunlight was linked together with a decrease in mortality rates due to some kind of cancer. (39). A study conducted on Norwegian patients with prostate, breast, and colon cancer patients by Robsahm et al it found that patients in seasons with much sun exposure had much better survival than in other seasons (40). However, randomized controlled trials of vitamin $D$ supplementation are required to define the causality of the relationship between vitamin $D$ and cancer risk. Since our study was retrospective, it was not possible to determine whether cancer patients took vitamin $D$ supplements or not. However, despite the possibility that there may be cancer patients taking vitamin $D$ supplementation in the population, only $21.7 \%$ of the patients had normal vitamin $\mathrm{D}$ levels. In addition, while vitamin $D$ levels do not show a significant difference in cancer patients in terms of age groups; there was also a significant difference in terms of sex and seasons. In this patient group, the sex with the highest deficiency in men $(61.9 \%)$, and the season in which it is most prevalent in winter (67.0\%). For this reason, we think that there can be a contrary correlation between vitamin $\mathrm{D}$ level and cancer, although the benefits of vitamin D for some cancers are controversial, deficiency of vitamin $D$ should be seen as a risk for many types of cancer, and normal levels of it have a protective effect. In this context, it is critical to ensure normal blood levels of vitamin $\mathrm{D}$ to protect against cancer.

In studies conducted in our country and abroad, it has been reported that $25(\mathrm{OH}) \mathrm{D}$ levels of females are lower than men, and 25(OH)D deficiency is more common in women. This difference between the sex in 25(OH)D levels are thought to be because women benefit less from sunlight due to religious and socio-cultural reasons, which determine their dressing style, and the limitation of the time spent in open areas (41). In the study conducted by Mansoor et al. in Pakistan, the average vitamin D level in 123 healthy adults was found to be $41.1 \pm 9.6 \mathrm{nmol} / \mathrm{L}(16.44 \mathrm{ng} / \mathrm{mL})$. In the same study, $69.9 \%$ of the participants in the study found that 25(OH)D levels were deficient and $21.1 \%$ were insufficient (90\% in total) (42). Hekimsoy et al. on people living in a region that generally receives sunlight throughout the year, such as the Aegean region of our country, found $25(\mathrm{OH}) \mathrm{D}$ deficiency as $74.9 \%$ and $25(\mathrm{OH}) \mathrm{D}$ deficiency as $13.8 \%$. Moreover, 25(OH)D deficiency was observed with a higher rate in women (78.7\%) than men (66.4\%) (41). In some studies, it has been reported that serum 25(OH)D levels varies seasonally and reaches their highest levels in the summer months (43). In the article studied by Öğüş et al. in Ankara, they found the mean of vitamin D levels of 3242 patients as $22.80 \pm 13.27$ $\mathrm{ng} / \mathrm{mL}$, and vitamin $\mathrm{D}$ levels $<20 \mathrm{ng} / \mathrm{mL}$ on $47 \%$ of the patients (50\% in women, 38\% in men). (44). In our study, the distribution of all 5563 patients in terms of sex, diseases, seasons, and age groups was also examined. There was no significant difference between the levels of vitamin $D$ between women and men. Telo et al., in their study examining the change of vitamin $D$ concentration in the Elazığ region as to age, season, and sex, found the lowest $25(\mathrm{OH}) \mathrm{D}$ levels in both women and men in winter and the highest level in summer and found a significant difference between seasons (45). In a study by Çatak et al., in which 2742 people looked at vitamin D levels, the lowest of it was observed in winter and the highest of it in summer (46). In our study, seasonally the highest levels were monitored in the summer season and the lowest levels were observed in 
the winter season for vitamin D. Considering the age group, the highest deficiency in vitamin D was seen in $14 \%(n=775)$ in the 18-34 age group, and the highest deficiency in the 017 age group among all patients.

\section{CONCLUSION}

In conclusion, while vitamin D levels were deficient and insufficient in obesity, cancer, and CKD patients, there was no difference in terms of gender. We also found that vitamin $D$ levels differed in terms of season and age groups. There are literature studies in which VDD is present even in healthy individuals. In this respect, especially in diseases such as cancer, obesity, CKD that require vitamin $D$ supplementation, supplementation doses should be adjusted in terms of the age of the patient and season. Therefore, we think that our study will make an important contribution to the literature.

Etik: Bu çalışmanın etik kurul onayı alınmıştır (IU 12.10.2018, number: 2018/12-10).

Ethics committee approval had been taken (IU 12.10.2018, number: 2018/12-10).

Yazar katkı durumu; Çalışmanın konsepti; NB, FÖB, dizaynı; NB, Literatür taraması; NB, FÖB, verilerin toplanması ve işlenmesi; NB, MÇT, istatistik; NB, MÇT, yazım aşaması; NB, NB, MÇT

Author contribution status; Idea/Concept: NB, FÖB, Design: NB, Data Collection/Processing: NB, FÖB, Analysis /Interpretation: NB, MÇT, Literature Review: NB Drafting/Writing: NB Critical Review: NB, MÇT

Yazarlar arasında çıkar çatışması yoktur.

The author declares no conflict of interest.

Finansal Destek: yoktur / Funding: none doi: https://doi.org/10.33713/egetbd.951441

\section{REFERENCES}

1. Wacker M, Holiack MF. Vitamin D affects skeletal and extraskeletal health and the need for supplementation. Nutrients. 2013;5(1):111-48.

2. 2. Pittas AG, Chung $M$, Trikalinos $T$, Mitri J, Brendel $M$, Patel K, et al. Vitamin D, and Cardiometabolic Outcomes: A Systematic Review Anastassios. Ann Intern Med [Internet]. 2011;152(5):307-14. Available from: https://www.ncbi.nlm.nih.gov/pmc/articles/PMC3211092/pdf/ni hms332580.pdf
3. 3. Thacher TD, Clarke BL. Vitamin D insufficiency. Mayo Clin Proc. 2011;86(1):50-60.

4. Hossein-nezhad A, Spira A, Holick MF. Influence of Vitamin D Status and Vitamin D3 Supplementation on Genome-Wide Expression of White Blood Cells: A Randomized Double-Blind Clinical Trial. PLoS One. 2013;8(3).

5. Cemile B, Neşe T. D vitAMiniSentezi,Metabolïzmasi Ve SağlikÜzerìnEtkileri. Gazi Sağlık Bilim Derg. 2021;6(1):33-47.

6. Vurgun E, Evliyaoğlu O, Yıldırmak S. Evidence-based laboratory: Determining the insufficiency level of vitamin D. Haseki Tip Bul. 2016;54(2):76-82.

7. Holick MF. Medical progress: Vitamin D deficiency. N Engl J Med. 2007;357(3):266-81.

8. Yavuz D, Mete T, Yavuz R, Altunoğlu A. D Vitamini, Kalsiyum \& Mineral Metabolizması, D Vitaminin İskelet Dışı Etkileri ve Kronik Böbrek Yetmezliğinde Nütrisyonel D Vitamini Kullanımı. Ankara Med J. 2014;14(4):162-71.

9. Marquardt P, Krause R, Schaller M, Bach D, Von Gersdorff G. Vitamin $D$ status and cancer prevalence of hemodialysis patients in Germany. Anticancer Res. 2015;35(2):1181-7.

10. Wolf M, Shah A, Gutierrez O, Ankers E, Monroy M, Tamez H, et al. Vitamin $D$ levels and early mortality among incident hemodialysis patients. Kidney Int [Internet]. 2007;72(8):1004-13. Available from: http://dx.doi.org/10.1038/sj.ki.5002451

11. Elder GJ. Vitamin D levels, bone turnover and bone mineral density show seasonal variation in patients with chronic kidney disease stage 5. Nephrology. 2007;12(2):208.

12. Li YC, Kong J, Wei M, Chen Z-F, Liu SQ, Cao L-P. 1,25Dihydroxyvitamin D3 is a negative endocrine regulator of the renin-angiotensin system. J Clin Invest. 2002;110(2):229-38.

13. Yao $Y$, Zhu L, He L, Duan $Y$, Liang $W$, Nie $Z$, et al. A metaanalysis of the relationship between vitamin $D$ deficiency and obesity. 2015;8(9):14977-84.

14. Vimaleswaran KS, Berry DJ, Lu C, Tikkanen E, Pilz S, Hiraki LT, et al. Causal Relationship between Obesity and Vitamin D Status: Bi-Directional Mendelian Randomization Analysis of Multiple Cohorts. PLoS Med. 2013;10(2).

15. McGill AT, Stewart JM, Lithander FE, Strik CM, Poppitt SD. Relationships of low serum vitamin D3 with anthropometry and markers of the metabolic syndrome and diabetes in overweight and obesity. Nutr J. 2008;7(1):3-7.

16. Ding C, Gao D, Wilding J, Trayhurn P, Bing C. Vitamin D signalling in adipose tissue. Br J Nutr. 2012;108(11):1915-23.

17. Pereira-Santos M, Costa PRF, Assis AMO, Santos CAST, Santos DB. Obesity and vitamin D deficiency: A systematic review and meta-analysis. Obes Rev. 2015;16(4):341-9.

18. Wood RJ. Vitamin D and adipogenesis: New molecular insights. Nutr Rev. 2008;66(1):40-6.

19. Stefano A De, Ganini C, Scimeca M, Bochicchio F, Mazzotta A, Rovella V, et al. Role of Vitamin D in Obesity. 2021;25(6):362-78.

20. Blumberg JM, Tzameli I, Astapova I, Lam FS, Flier JS, Hollenberg AN. Complex role of the vitamin $D$ receptor and its ligand in adipogenesis in 3T3-L1 cells. J Biol Chem [Internet]. 2006;281(16):11205-13. Available from: 


\section{http://dx.doi.org/10.1074/jbc.M510343200}

21. Lee $H$, Bae $S$, Yoon $Y$. Anti-adipogenic effects of 1,25dihydroxyvitamin D3 are mediated by the maintenance of the wingless-type MMTV integration site/ $\beta$-catenin pathway. Int J Mol Med. 2012;30(5):1219-24.

22. Lagunova Z, Porojnicu LC, Lindberg F, Hexeberg S, Moan J. The dependency of vitamin $D$ status on body mass index, gender, age and season. Anticancer Res. 2009;29(9):3713-20.

23. Ernst B, Thurnheer M, Schmid SM, Wilms B, Schultes B. Seasonal variation in the deficiency of 25-hydroxyvitamin d3 in mildly to extremely obese subjects. Obes Surg. 2009;19(2):1803.

24. Bischof MG, Heinze G, Vierhapper $H$. Vitamin D status and its relation to age and body mass index. Horm Res. 2006;66(5):2115.

25. Park S, Ham JO, Lee BK. A positive association of vitamin D deficiency and sarcopenia in 50-year-old women, but not men. Clin Nutr [Internet]. 2014;33(5):900-5. Available from: http://dx.doi.org/10.1016/j.clnu.2013.09.016

26. B Öngen, C Kabaroğlu ZP. D Vitamini'nin Biyokimyasal ve Laboratuvar Dexerlendirmesi Biochemical. Cailiao Gongcheng/Journal Mater Eng. 2009;6(7):23-31.

27. Li M, Chen P, Li J, Chu R, Xie D, Wang H. Review: The impacts of circulating 25-Hydroxyvitamin $D$ levels on cancer patient outcomes: A systematic review and meta-analysis. J Clin Endocrinol Metab. 2014;99(7):2327-36.

28. Urbschat A, Paulus $P$, von Quernheim QF, Brück $P$, Badenhoop K, Zeuzem S, et al. Vitamin D hydroxylases CYP2R1, CYP27B1 and CYP24A1 in renal cell carcinoma. Eur J Clin Invest. 2013;43(12):1282-90.

29. Feldman D, Krishnan A V., Swami S, Giovannucci E, Feldman $B J$. The role of vitamin $D$ in reducing cancer risk and progression. Nat Rev Cancer [Internet]. 2014;14(5):342-57. Available from: http://dx.doi.org/10.1038/nrc3691

30. Sofi NY, Jain M, Kapil U, Seenu V, R. L, Yadav CP, et al. Reproductive factors, nutritional status and serum 25(OH)D levels in women with breast cancer: A case control study. J Steroid Biochem Mol Biol. 2018;175(August 2017):200-4.

31. Shi L, Nechuta S, Gao YT, Zheng Y, Dorjgochoo T, Wu J, et al. Correlates of 25-hydroxyvitamin D among Chinese breast cancer patients. PLoS One. 2014;9(1):14-6.

32. Rosen CJ, Adams JS, Bikle DD, Black DM, Demay MB, Manson $J A E$, et al. The nonskeletal effects of vitamin $D$ : An endocrine society scientific statement. Endocr Rev. 2012;33(3):456-92.

33. Zhang $Y$, Fang F, Tang J, Jia L, Feng $Y$, Xu $P$, et al. Association between Vitamin $D$ supplementation and mortality: Systematic review and meta-analysis. BMJ. 2019;366.

34. Welsh J. Cellular and Molecular effects of Vitamin D on Carcinogenesis. Arch Biochem Biophys [Internet]. 2012;523(1):107-14. Available from: https://www.ncbi.nlm.nih.gov/pmc/articles/PMC3624763/pdf/ni hms412728.pdf

35. Tangpricha V, Spina C, Yao M, Chen TC, Wolfe MM, Holick MF. Vitamin D deficiency enhances the growth of MC-26 colon cancer xenografts in Balb/c mice. J Nutr. 2005;135(10):2350-4.

36. Leyssens C, Marien E, Verlinden L, Derua R, Waelkens $E_{\text {, }}$ Swinnen J V., et al. Remodeling of phospholipid composition in colon cancer cells by $1 \mathrm{a}, 25(\mathrm{OH}) 2 \mathrm{D} 3$ and its analogs. J Steroid Biochem Mol Biol [Internet]. 2015; 148:172-8. Available from: http://dx.doi.org/10.1016/j.jsbmb.2015.01.018

37. John EM, Dreon DM, Koo J, Schwartz GG. Residential sunlight exposure is associated with a decreased risk of prostate cancer. J Steroid Biochem Mol Biol. 2004;89-90:549-52.

38. Hanchette CL, Schwartz GG. Geographic patterns of prostate cancer mortality. Evidence for a protective effect of ultraviolet radiation. Cancer. 1992;70(12):2861-9.

39. Freedman DM, Dosemeci M, McGlynn K. Sunlight and mortality from breast, ovarian, colon, prostate, and nonmelanoma skin cancer: A composite death certificate-based case-control study. Occup Environ Med. 2002;59(4):257-62.

40. Robsahm TE, Tretli S, Dahlback A, Moan J. Vitamin D3 from sunlight may improve the prognosis of breast-, colon- and prostate cancer (Norway). Cancer Causes Control. 2004;15(2):149-58

41. Hekimsoy Z, Dinç G, Kafesçiler S, Onur E, Güvenç Y, Pala T, et al. Vitamin $D$ status among adults in the Aegean region of Turkey. BMC Public Health. 2010;10.

42. Mansoor S, Habib A, Ghani F, Fatmi Z, Badruddin S, Mansoor $S$, et al. Prevalence and significance of vitamin $D$ deficiency and insufficiency among apparently healthy adults. Clin Biochem. 2010;43(18):1431-5.

43. Brot C, Vestergaard $P$, Kolthoff N, Gram J, Hermann AP, Sørensen $\mathrm{OH}$. Vitamin $\mathrm{D}$ status and its adequacy in healthy Danish perimenopausal women: relationships to dietary intake, sun exposure and serum parathyroid hormone. $\mathrm{Br} J$ Nutr. 2001;86(S1): S97-103.

44. Ögǚ̈ş E, Sürer H, Kılınç AŞ, Fidancı V, Yılmaz G, Dindar N, et al. D Vitamini Düzeylerinin Aylara, Cinsiyete ve Yaşa Göre Değerlendirilmesi. Ankara Med J. 2015;15(1):1-5.

45. Telo S, Kaman D, Akgöl G. Klinik Araştırma Elazı̆̆ ilinde D Vitamini Düzeylerinin Yaş, Cinsiyet ve Mevsimlere Göre Değişimi. Firat Med J. 2017;22(1):29-33.

46. çatak zekiye. Elazı̆̆ Bölgesinin 25 Hidroksivitamin D Düzeylerinin Değe $r$ lendirilmesi ve Populasyona Dayalı Yeni Referans Aralıklarının Belirlenmesi. 2018;23(1):6-10. 